\title{
Radioisotopic studies of DNA biosynthesis in relation to growth of Zea mays roots
}

ROMAN MAKSYMOWYCH. ANDREW B. MAKSYMOWYCH JOSEPH A. J. ORKWISZEWSKI

Department of Biology. Villanova University, Villanova. Pennsylvania 19085. USA (Received: August 15. 1985. Accepted: October 7. 1985)

\begin{abstract}
Root growth consists of two basic processes, cell division and cell elongation. An integral part of the first process is the synthesis of deoxyribonucleic acid (DNA). DNA biosynthesis was studied in primary roots of Zea mays through incorporation of ${ }^{3} \mathrm{H}$-thymidine by autoradiography and liquid scintillation spectrometry. DNA synthesis was restricted to the meristematic region of the primary root. The curve representing this process was bell-shaped with a peak at $1.5 \mathrm{~mm}$ from the tip. Up to $3 \mathrm{~mm}$ distance from the tip, the root was growing both by cell division and cell elongation. This was also the region of DNA synthesis. The root region between 3 to $9 \mathrm{~mm}$ from the tip. was growing only by cell elongation. The relative elemental rate of elongation had a maximum at $3.5 \mathrm{~mm}$ from the tip. or shortly after cessation of DNA synthesis and cell division. Cells stopped elongating at $9 \mathrm{~mm}$ distance from the tip.
\end{abstract}

Key words: DNA biosynthesis, primary roots, Zea mays

\section{INTRODUCTION}

Tritium labeled thymidine has been extensively used in investigations of cell division, cell cycles and DNA biosynthesis in various tissues. Studies on the incorporation of this DNA precursor by developing roots have been made by Pelc and LaCour (1959), Clowes (1959), Jensen et al. (1955, 1960), Rao (1962), Evans (1964) and others. The duration of mitotic cycles in root tip cells was determined by Wimber (1960) for Tradescantia palludosa, Van't Hoff and Huen-Kuen Ying (1964) for Pisum sativum and other investigators. For a more extensive review of research in this area readers are referred to Clowes (1976).

The most recent critical reviews of cell division and other physiological 
processes in root apical meristem are by Barlow (1976) and Feldman (1984). Barlow (1976) attempted to construct a model that explains the behavior of cells in the root apex. He proposed that hormonal gradients may account for differences in the growth rate of cells in the root apex. The physiological basis of organization and development in the root and the role of the quiescent center in vascular tissue differentiation was discussed by Torrey (1965) and Feldman and Torrey (1975).

Little information is available concerning ${ }^{3} \mathrm{H}$-thymidine incorporation into nuclear DNA as a function of the distance from the tip and its relation to root growth. Rao (1962) studied DNA biosynthesis in Zea mays roots utilizing autoradiographic techniques and Jensen et al. (1960) made similar studies with Alium cepa. Their investigations, however, were limited to the meristematic region only, without specific reference to the relative elemental growth rates of these roots.

The purpose of this investigation was to study DNA biosynthesis in various parts of corn roots in relation to root growth expressed in terms of relative elemental rates of cell division and elongation. It was also hoped that correlation could be made with earlier studies of these processes (Erickson and Goddard 1951, Erickson and Sax 1956a, 1956b). The average percent of labeled nuclei with ${ }^{3} \mathrm{H}$-thymidine represents the relative number of cells in a cell population engaged in DNA synthesis (Maksymowych 1973). It has been established that thymidine is incorporated into nuclei of cells synthesizing DNA prior to mitosis.

\section{MATERIAL AND METHODS}

Zea mays seeds were purchased from Carolina Biological Supply Company. They were soaked in distilled water and aerated overnight. The seeds were planted in Pyrex dishes on two layers of moist filter paper covered with another layer of moist filter paper and a sheet of glass. They were grown in a darkroom with temperature adjusted to $25^{\circ} \mathrm{C}$. When primary roots reached a length of about $4 \mathrm{~cm}$ they were used either in autoradiographic experiments or for liquid scintillation spectrometry.

Autoradiographic methods. Tritiated thymidine $\left(5 \mu \mathrm{Ci} \cdot \mathrm{cm}^{-3}\right.$; sp. act. $20 \mathrm{Ci} \cdot \mathrm{mM}^{-1}$ ) was introduced by absorption from aqueous solution. Ten seedlings were placed in a vial covered with two layers of cheesecloth with holes enlarged to facilitate the insertion of roots into the radioisotopic solution. The solution was aerated by bubbling a fine stream of air by means of a capillary pipette to increase oxygen concentration. The temperature of the solution was adjusted to $25^{\circ} \mathrm{C}$. Seedlings were removed from the radioisotopic solution after 15, 20, $30 \mathrm{~min}$ and $1 \mathrm{~h}$ of growth. After 
a brief rinse in distilled water $10 \mathrm{~mm}$ long root tips were cut off from the seedlings and fixed overnight in a 3 to 1 mixture of ethyl alcohol and glacial acetic acid. After dehydration in a series of mixtures of alcoholic solution and embedding in "Tissue Prep", $8 \mu \mathrm{m}$ near median, longitudinal sections were cut, stained with Feulgen and dipped into NTB-2 Kodak Nuclear Track Emulsion (Jensen 1962, Rogers 1967). After drying for $24 \mathrm{~h}$ slides with sections of roots grown for 15 and $20 \mathrm{~min}$ in the radioisotopic solution were exposed to the emulsion for 5 weeks at $4{ }^{\circ} \mathrm{C}$. Those with $1 \mathrm{~h}$ and $30 \mathrm{~min}$ growth were exposed for 1 and 2 weeks, respectively. Slides were developed for $5 \mathrm{~min}$ in Kodak D-19 developer and put into Kodak Acid Fixer for $10 \mathrm{~min}$. The procedure from dipping to the Acid Fixer step was carried out in a dark room. Dehydration was performed in a series of mixtures of alcoholic solutions up to $100 \%$ concentration and xylene. "Permount" was used to attach coverslips for permanent preparations. A Bausch and Lomb Whipple ocular micrometer was used for estimation of the percentage of labeled nuclei along the cortical regions from the root tip, covering a distance of $10 \mathrm{~mm}$ in the basipetal direction.

In the analysis of the autoradiographic slides, nuclei with four grains or more were considered as specifically labeled. This was estimated by Chi-square tests from the number of grains in the emulsion (background radiation) and nuckear area.

Tissue shrinkage. Tissue shrinkage was estimated separately for $10 \mathrm{~mm}$ long root tips and segments of the root tips. For the first group, root tips approximately $10 \mathrm{~mm}$ long were cut off from germinated Zea mays seedlings on moist filter paper and processed under conditions identical to those for autoradiographic experiments. In the second experiment root tips were cut into ten $1 \mathrm{~mm}$ segments; the first segments labeled with number I included tip and root caps; segments No. X were the last basal segments. The lengths of the root tips and the segments were measured with a vernier caliper under a dissecting microscope with accuracy of about $100 \mu \mathrm{m}$ with an error of approximately $0.7 \%$. The tissue was then fixed overnight in a 3 to 1 mixture of ethyl alcohol and glacial acetic acid and dehydrated the following day as described earlier. When the tissue was in $70 \%$ alcohol, ten drops of Fast Green dye were added to render the segments and root tips more visible, especially during paraffin infiltration and embedding. After the tissue was embedded in "Tissue Prep", the root tips and 'segments were cut off from paraffin blocks and put into vials containing xylene. The vials with xylene and tissues were kept for $4 \mathrm{~h}$ in a paraffin oven adjusted to $60^{\circ} \mathrm{C}$ to accelerate dissolving of paraffin. Then, the lengths of the root tips and segments were measured again with a vernier caliper under a dissecting microscope. The average 
shrinkage of the $10 \mathrm{~mm}$ long root tips was $15.8 \%$ whereas the average shrinkage of the segments was $10.9 \%$. There was less shrinkage in basal segments. From regression analysis where the percent of shrinkage was plotted as a function of the distance from the tip, it was estimated that the shrinkage of the basal segments fluctuated between $7 \%$ and $10 \%$, and for the apical segments it fluctuated between $11 \%$ and $14 \%$.

Liquid scintillation spectrometry. After $1 \mathrm{~h}$ of growth in ${ }^{3} \mathrm{H}$-thymidine solution $\left(5 \mu \mathrm{Ci} \cdot \mathrm{cm}^{-3}\right)$ under conditions similar to those in autoradiographic experiments, root tips were cut into segments using a jig similar to the one described by Erickson and Sax (1956a, p. 501). Ten root tips were placed in the jig and simultaneously cut into ten $1 \mathrm{~mm}$ segments. The segments were numbered I to X. Number I segments included the root caps; number $\mathrm{X}$ were the last basal segments. The segments wére put overnight in a fixative solution (mixture of $3: 1$ ethyl alcohol and glacial acetic acid). Each set of segments was homogenized in small size "Kontes" brand glass homogenizers in $1 \mathrm{~cm}^{3}$ of absolute ethyl alcohol. After $5 \mathrm{~min}$ of grinding, the cell suspension was transferred to glass counting vials (New England Nuclear Corp (NEN)) containing Liquifluor (NEN) and CAB-O-SIL. CAB-O-SIL was used to insure that the ground particles remained in uniform suspension. It is a compound of silica oxide which does not cause a significant amount of quenching in liquid scintillation counting. The vials were filled almost to the top with Liquifluor and placed in an aspirator jar attached to a vacuum pump. Air was removed by drawing a vacuum for about $30 \mathrm{~min}$. The vials were tightly closed with screw-type plastic caps, shaken and counted. A Nuclear Chicago Liquid Scintillation Spectrometer was used. The amount of quenching in each vial was determined by the channel-ratio method. This method is based on the principle that when quenching occurs, the heights of energy pulses, on the average, decrease and the spectrum shifts toward lower energy. If the energy spectrum is divided into two counting channels, the ratio of count rates in two channels will change in a predictable way and is directly related to the amount of quenching. Since the highest theoretical ${ }^{3} \mathrm{H}$-counting is $38 \%$, cpm values of all vials counted were adjusted to $38 \%$ efficiency level thus compensated for variability among vials due to quenching differences. For a more detailed description of techniques and methods of calculations involved in relative elemental rates of cell division and cell elongation, readers are referred to Erickson and Goddard (1951) and Erickson and Sax (1956a).

\section{RESULTS}

Autoradiographic slides containing sections of roots grown 15, 20, 30 $\min$ and $1 \mathrm{~h}$ in ${ }^{3} \mathrm{H}$-thymidine were analyzed and the percent of labeled 


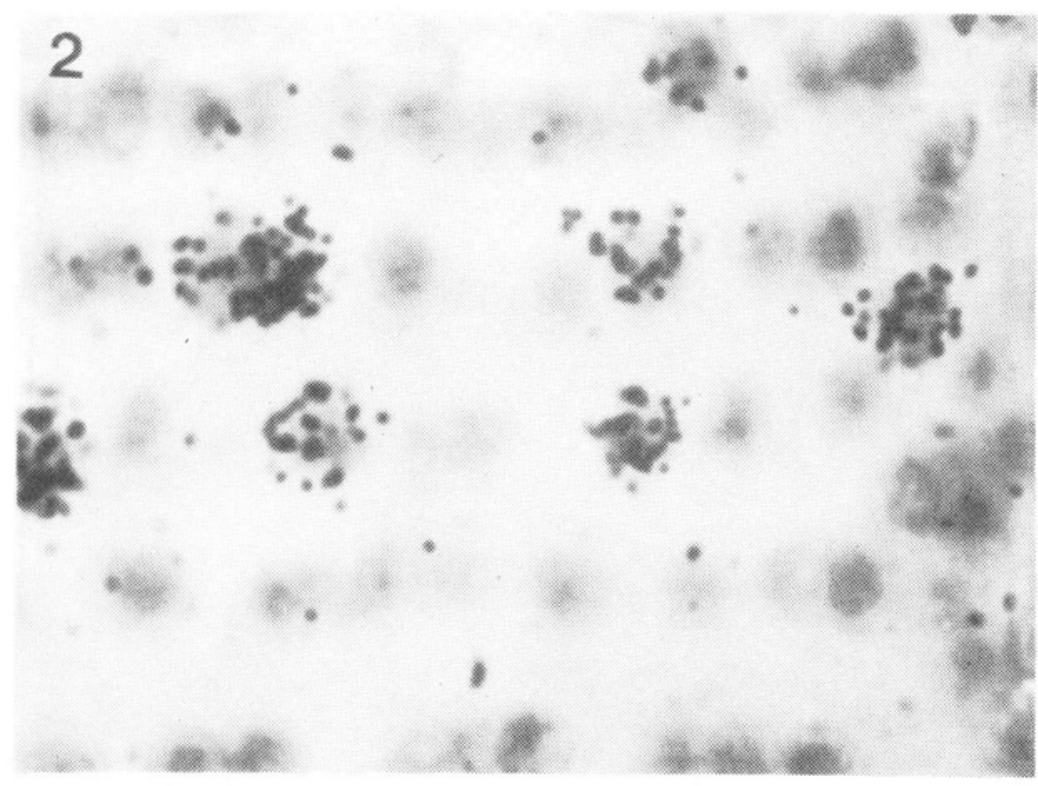

Fig. 2. Autoradiograph of a longitudinal section of Zea mays root tip showing a portion of cortical nuclei at the meristematic region. The grains over some nuclei represent relative amounts of ${ }^{3} \mathrm{H}$-thymidine incorporated into DNA 
nuclei determined as a function of the distance from the tip. The curve obtained from the analysis of $20 \mathrm{~min}$ growth in ${ }^{3} \mathrm{H}$-thymidine is illustrated in Fig. 1. In this graph the percent of labeled nuclei is plotted against distance from the tip. DNA synthesis is low in the first segment, it increased rapidly in the apical meristem, reaching maximum at about $1.5 \mathrm{~mm}$ distance from the tip. Then the curve declined rapidly to zero shortly after $4 \mathrm{~mm}$.

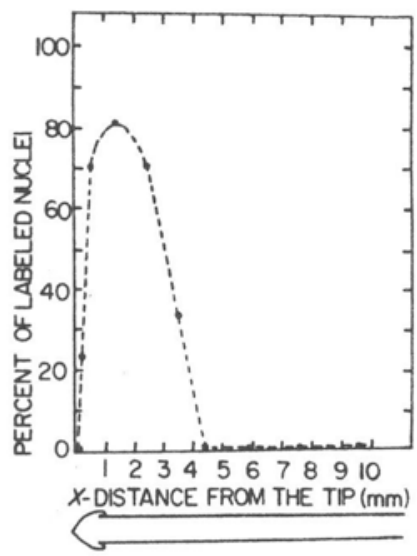

Fig. 1. Percent of labeled nuclei with ${ }^{3} \mathrm{H}$-thymidine representing DNA biosynthesis in the primary root of Zea mays is plotted as a function of the distance from the tip

The whole curve can be approximated to a bell-shaped curve and is similar in shape to the curves obtained from 15 and $30 \mathrm{~min}$ and $1 \mathrm{~h}$ analyses. Curves obtained from these analyses had peaks fluctuating between 1.5 and $2 \mathrm{~mm}$ distance from the tip. The graph obtained from a $20 \mathrm{~min}$ analysis was chosen because it approximates pulse-labeled conditions. Infrequently one could find labeled nuclei beyond $3 \mathrm{~mm}$ from the tip. This was perhaps due to the endomitotic synthesis of DNA in a region removed from the apical meristem in a basipetal direction. An example of cortical nuclei labeled with ${ }^{3} \mathrm{H}$-thymidine is illustrated in Fig. 2. The grains over nuclei represent relative amounts of ${ }^{3} \mathrm{H}$-thymidine incorporated in DNA. Figure 3 represents a composite graph obtained from liquid scintillation spectrometry and cell division data. The histogram bars represent counts per minute (cpm), corrected for quenching. The highest incorporation of ${ }^{3} \mathrm{H}$-thymidine was in the second $\mathrm{mm}$ segment of the Zea mays root.

Figure 4 represents basic kinetics of Zea mays root growth reproduced from Erickson and Saxs' (1956a) data with atuhors' and editors' permission. Two parameters of growth, relative elemental rates of cell division $[\mathrm{d}(\mathrm{dC} / \mathrm{dt}) / \mathrm{dC}]$ and relative elemental rates of elongation $[\mathrm{d}(\mathrm{dX} / \mathrm{dt}) \mathrm{dX}]$ were plotted vs. distance from the tip in $\mathrm{mm}$. Relative elemental rate of elongation can 


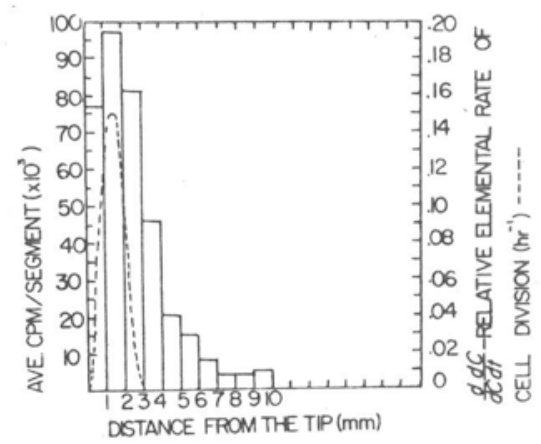

Fig. 3. Histogram bars represent counts per minute (cpm), the dashed line curve relative elemental rates of cell division. Both are plotted as a function of the distance from the root tip

be defined as a rate of elongation of a minute segment of the root relative to its size as a function of its distance from the tip. In a sense it represents distribution of rates of cell division and cell elongation along the longitudinal axis of the primary root. Some basic conclusions can be drawn from Fig. 4. Growth of the primary root of Zea mays is

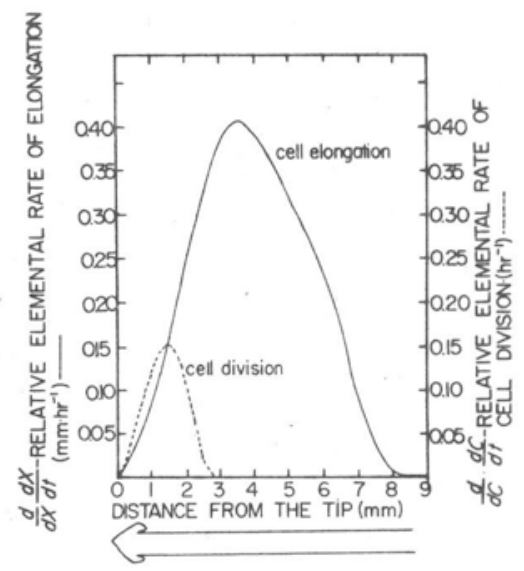

Fig. 4. Solid line represents relative elemental rates of elongation and the dashed line relative elemental rates of cell division. The former curve has a peak at $3.5 \mathrm{~mm}$ from the tip, the latter curve at $1.5 \mathrm{~mm}$ from the tip. This graph was reproduced from Erickson and Sax (1956) by Authors' and Editors' permission

composed of two processes, cell division and cell elongation. Up to $3 \mathrm{~mm}$ from the tip, the root grows by cell division and cell elongation. From $3 \mathrm{~mm}$ from the tip up to $9 \mathrm{~mm}$, it grows only by cell elongation. The relative elemental rates of these processes are not constant but can be 
approximated to bell-shaped curves. The relative elemental rate of cell division had its maximum at $1.5 \mathrm{~mm}$ from the tip $[\mathrm{d}(\mathrm{dC} / \mathrm{dt}) / \mathrm{dC}]=0.154 \mathrm{hr}^{-1}$; cell division stopped after $3 \mathrm{~mm}$. Rates of cell elongation were small during the period of cell division. However, they increased in the basipetal direction and reached a maximum at $3.5 \mathrm{~mm}[\mathrm{~d}(\mathrm{dX} / \mathrm{dt}) / \mathrm{dX}]=0.406 \mathrm{hr}^{-1}$. There was no elongation after $9 \mathrm{~mm}$ from the tip.

Figure 3 represents average counts per $\min (\mathrm{cpm})$ obtained from ${ }^{3} \mathrm{H}$-thymidine incorporation and assessment of radioactivity by liquid scintillation spectrometry. The first segment which contained the root cap and part of the meristematic region has a lower amount of ${ }^{3} \mathrm{H}$-thymidine than the second segment. This is to be expected since the 2nd segment contained most of the meristematic tissue with a high capacity of. DNA biosynthesis and cell division. Segments positioned basipetally to the apical meristem (after $2 \mathrm{~mm}$ ) showed progressively lower incorporation of ${ }^{3} \mathrm{H}$-thymidine. Mature segments incorporated small amounts of the radioisotope which was located mostly in the cytoplasm and among cell wall fibrils.

Figure 1 represents percent of labeled nuclei plotted as a function of the distance from the tip. Data for this graph were obtained from autoradiographic analysis and they represent DNA biosynthesis as a function of the distance from the tip. The curve representing this biosynthetic process is an assymetrical bell-shaped curve with a peak approximately at $1.5 \mathrm{~mm}$ distance from the tip, which is the region of high mitotic activity. Segments of the mature region of the root show little incorporation. Perhaps this incorporation could be associated with endomitotic DNA biosynthesis.

\section{DISCUSSION}

Three processes associated with DNA synthesis, i.e., incorporation of ${ }^{3} \mathrm{H}$-thymidine assessed by liquid scintillation spectrometry, percent of labeled nuclei obtained in autoradiographic analysis and relative elemental rates of cell division can be correlated. Data of the last two parameters are most directly related to DNA biosynthesis. Only those cells which were engaged in a DNA-biosynthetic process incorporated exogenous thymidine. Cell division and DNA synthesis are parts of the same cell cycle with DNA replication ( $\mathrm{S}$ phase) preceding cell division.

Even though ${ }^{3} \mathrm{H}$-thymidine incorporation (cpm vs. distance from the tip) in basal segments was not directly indicative of cell division there is no doubt that the high incorporation observed in the meristematic region around $1.5 \mathrm{~mm}$ from the tip was associated with this process. The agreement among Figs. 1 and 3 and the cell division curve of Fig. 4 is striking. 
All three processes are represented by bell-shaped curves which can be superimposed with peaks roughly at $1.5 \mathrm{~mm}$ from the tip.

Since ${ }^{3} \mathrm{H}$-thymidine incorporation assessed by liquid scintillation spectrometry may not necessarily be DNA specific, it should be considered as indirect evidence for DNA biosynthesis in the meristematic region. There is evidence (Maksymowych 1973) that when cells are supplied with exogenous ${ }^{3} \mathrm{H}$-thymidine, these molecules can be metabolized and the labeled fraction incorporated in the cell wall. Nevertheless, correlation of peaks at $1.5 \mathrm{~mm}$ from the tip, in graphs 1,3 and 4 obtained from autoradiographic analysis, ${ }^{3} \mathrm{H}$-thymidine incorporation and rate of cell division is warranted since one deals here with interrelated processes. La mbert (1967) studied thymidine incorporation into root cells of Vicia faba. From autoradiographic analyses, she established the basic kinetics of ${ }^{3} \mathrm{H}$-thymidine incorporation. In addition to percent of labeled nuclei as a function of distance from the tip, the author assessed the average number of grains per average labeled nucleus. This parameter estimates the relative amount of the radioisotopic precursor incorporated into the DNA of a single nucleus. She obtained a bell-shaped curve with a broad peak between 1.5 and $2.0 \mathrm{~mm}$ from the tip.

Jensen et al. (1960) studied incorporation of ${ }^{3} \mathrm{H}$-thymidine in the meristematic region of Alium cepa. The percent of labeled nuclei was almost twice the percent of mitotic figures.

Perhaps the most appropriate correlation of our results can be made with those presented by Rao (1962) who investigated the incorporation of ${ }^{3} \mathrm{H}$-thymidine in the apical $3 \mathrm{~mm}$ segments of Zea mays roots. $\mathrm{He}$ obtained a bell-shaped curve with high proportion of labeled nuclei throughout the meristematic region between 1.0 and $2.5 \mathrm{~mm}$. As in our studies Lambert (1967) also reported that there was occasional incorporation of ${ }^{3} \mathrm{H}$-thymidine in Vicia faba in segments beyond the $3 \mathrm{~mm}$ region. Her interpretation was that DNA synthesis took place without cell division, a process known as endomitosis.

Although mitosis is an indirect indicator of prior DNA synthesis, incorporation of the precursor does not presuppose that cell duplication has taken place. Incorporation of ${ }^{3} \mathrm{H}$-thymidine into cells of the elongation region was reported by Pelc and LaCour (1959) in Vicia faba roots. Similar observations have been made by Jensen et al. (1960) in root cells of Alium cepa and Rao (1962) in Zea mays. The latter author attributed this phenomenon to the synthesis of DNA in cells in their terminal interphase which may be related to endomitosis, polysomaty, and the like. Maksymowych et al. $(1966,1967)$ observed that there was no incorporation of ${ }^{3} \mathrm{H}$-thymidine into leaf nuclei of Xanthium pennsylvanicum in tissues where cell division has ceased. 
Holmes et al. (1955) indicated that the mean DNA content per cell increased as a function of the distance from the root apex.

Evans (1964) suggested the possibility that variable grain counts could result from different rates of ${ }^{3} \mathrm{H}$-thymidine uptake in different regions of Vicia faba roots. Rao (1962) expressed a similar view of the existence of different populations of nuclei within specific root zones with reference to the duration of the cell cycle.

Maksymowych (1973) found that leaf lamina cells in meristematic condition showed a larger proportion of labeled nuclei but the average number of grains per labeled nucleus was significantly smaller in this tissue than in cells which were in early stages of enlargement. Apparently more radioisotopic DNA precursor was available to these latter cells. This indicated that stages of development, which may be somewhat analogous to various zones of roots, affect incorporation of exogenous DNA precursors. The main conclusions derived from these experiments are:

1. A growth period of 15 to $30 \mathrm{~min}$ in radioisotopic solution appears to be a suitable time for labeling of Zea mays root nuclei.

2. The meristematic region was most active in DNA biosynthesis, with the peak of activity at about $1.5 \mathrm{~mm}$ from the tip.

3. DNA biosynthetic activity stopped shortly after $4 \mathrm{~mm}$ from the tip.

4. Incorporation of ${ }^{3} \mathrm{H}$-thymidine into nuclear DNA took place in some nuclei in regions of cell elongation and maturation.

5. These data provide biochemical evidence which corroborate the results obtained by Erickson and Sax (1956a).

\section{REFERENCES}

Barlow P. W., 1976. Towards an understanding of the behavior of root meristems. J. Theor. Boil. 57: 433-451.

Clowes F. A. L.. 1959. Apical meristems of roots. Biol. Rev. 34: 501-529.

Clowes F. A. L., 1976. Cell division in higher plants. M. M. Yeoman (ed.), Academic Press, London-New York-San Francisco. pp. 254-284.

Erickson R. O., Goddard D. R.. 1951. An analysis of root growth in cellular and biochemical terms. Growth Supl. 10: 89-116.

Erickson R. O., Sax K. B., 1956a. Rates of cell division and cell elongation in the growth of the primary root of Zea mays. Proc. Amer. Phil. Soc. 100: 499-512.

Erickson R. O., Sax K. B., 1956b. Elemental growth rate of the primary root of Zea mays. Proc. Amer. Phil. Soc. 100: 487-498.

Evans H. J., 1964. Uptake of ${ }^{3} \mathrm{H}$-thymidine and patterns of DNA replication in nuclei and chromosomes of Vicia faba. Exp. Cell Res. 35: 381-393.

Feldman L. J., 1984. The development and dynamics of the root apical meristem. Amer. J. Bot. 71 (9): 1308-1314.

Feldman L. J., Torrey J.G., 1975. The quiescent center and vascular tissue pattern formation in cultured roots of Zea. Can. J. Bot. 53: 2796-2803. 
Holmes B. E., Mee L. K., Hornsy S., Gray L. H., 1955. The nucleic acid content of cells in the meristematic, elongating and fully elongated segments of roots of Vicia faba. Exp. Cell Res. 8: 101-113.

Jensen W. A., 1962. Botanical histochemistry. W. H. Freeman Co., San Francisco. pp. 76-89, 246-250.

Jensen W. A., Kavaljian L. G., Martinot S., 1955. A morphological and biochemical analysis of the early phases of cellular growth in the root tip of Vicia faba. Exp. Cell Res. 8: 506-522.

Jensen W. A., Kavaljian L. G., Martinot S., 1960. The incorporation of ${ }^{3} \mathrm{H}$-thymidine by developing root tip cells. Exp. Cell Res. 20: 361-367.

Lambert J. C., 1967. Incorporation of ${ }^{3} \mathrm{H}$-thymidine into roots cells of Vicia faba. M. S. Thesis, Villanova University, Villanova, $\mathrm{Pa}$.

Maksymowych R., 1973. Analysis of leaf development. Cambridge University Press. Cambridge, U.K.

Maksymowych R., Blum M. K., Devlin R. G., 1966. Autoradiographic studies of the synthesis of nuclear DNA in various tissues during leaf development of Xanthium pennsylvanicum. Develop. Biol. 13: 250-265.

Maksymowych R., Devlin R. G., Blum M. K., Wochok Z.S., 1967. ${ }^{3}$ H-thymidine incorporation into nuclear DNA of leaf cells. Plant Physiol. 42: 814-818.

Pelc S. R., LaCour L. F., 1959. The incorporation of thymidine in newly differentiated nuclei of roots of Vicia faba. Exp. Cell Res. 15: 131-133.

Rao H. V. Ramachrishna, 1962. Autoradiographic studies with corn root using tritiated thymidine. Ph. D. Dissert., University of Pennsylvania, Philadelphia, Pa.

Rogers A. W., 1967. Techniques of autoradiography. Elsevier Publ. Co., New York.

Torrey J. G., 1965. Physiological basis of organization and development in the root. In: Encyclopaedia of plant physiology. W. Ruhland (ed.). Springer, Berlin-Heidelberg-New York.

Van't Hoff J., Huen-Kuen Ying, 1964. Simultaneous marking of cells in two different segments of the mitotic cycle. Nature 202: 981-983.

Wimber E. D., 1960. Duration of the nuclear cycle in Tradescantia palludosa root tips as measured with ${ }^{3} \mathrm{H}$-thymidine. Amer. J. Bot. 47: 828-833.

\section{Badania radioizotopowe biosyntezy DNA $w$ powiqzaniu $z$ wzrostem korzeni u Zea mays}

\section{Streszczenie}

Wzrost korzeni polega na dwóch podstawowych procesach, na podziale komórek i ich wydłużaniu się. Integralną częścią pierwszego procesu jest synteza kwasu dezoksyrybonukleinowego (DNA). Biosyntezę DNA badano w korzeniach pierwotnych Zea mays, obserwując wbudowywanie ${ }^{3} \mathrm{H}$-tymidyny metodą autoradiografii i płynnej spektrometrii scyntylacyjnej. Synteza DNA ograniczała się do regionu merystematycznego korzeni pierwotnych. Wykres obrazujący ten proces miał kształt dzwonu ze szczytem $1.5 \mathrm{~mm}$ od wierzcholka. W odległości ponad $3 \mathrm{~mm}$ od wierzchołka korzeń wykazywał wzrost zarówno przez podział, jak i przez wydłużanie się komórek. Był to również obszar syntezy DNA. Region korzenia między 3 a $9 \mathrm{~mm}$ od wierzchołka rósł jedynie dzięki wydłużaniu się komórek. Względne, podstawowe tempo wydłużania się miało maksimum na wysokości $3,5 \mathrm{~mm}$ od wierzchołka albo zaraz za miejscem zaniku syntezy DNA i podziału komórek. Komórki przestały wydłużać się w odległości $9 \mathrm{~mm}$ od wierzchołka. 